\title{
ATMOSPHERIC RADIOCARBON AT THE END OF THE LAST GLACIAL: AN ESTIMATE BASED ON AMS RADIOCARBON DATES ON TERRESTRIAL MACROFOSSILS FROM LAKE SEDIMENTS
}

\author{
HUGO ZBINDEN, MICHAEL ANDREE, HANS OESCHGER \\ Physics Institute, University of Bern, Switzerland
}

BRIGITTA AMMANN, ANDRE LOTTER

Systematic Geobotanic Institute, University of Bern, Switzerland

GEORGES BONANI and WILLY WÖLFLI

Eidgenössische Technische Hochschule, Zürich, Switzerland

\begin{abstract}
The main purpose of this work is to reconstruct the atmospheric $\Delta^{14} \mathrm{C}$ in the glacial-postglacial transition, $14,000-10,000 \mathrm{BP}$, a range not covered by the tree-ring calibration curve. We measured ${ }^{14} \mathrm{C} /{ }^{12} \mathrm{C}$ ratios on series of terrestrial macrofossils from sediments of ration curve. We measured ${ }^{14} \mathrm{C} / \mathrm{C}^{12} \mathrm{C}$ ratios on series of terrestrial macrofossils from sem lakes. We selected exclusively plant remains of recognizable terrestrial origin that are not affected by hard water and thus reflect atmospheric ${ }^{14} \mathrm{C}$ concentration. Due to the scarcity of such material, we used accelerator mass spectroscopy. Cores of two lakes were measured to eliminate local effects and to check the reproducibility of results. This required a reliable, ${ }^{14} \mathrm{C}$-independent correlation of the cores, obtained through local pollen zone boundaries. ${ }^{14} \mathrm{C}$ ages were obtained as a function of the depth in the cores. If sedimentation rates are known, ages can be converted into $\Delta^{14} \mathrm{C}$ values. We also attempted estimating sedimentation rates; calculations are based on the Swedish varve chronology. Results were combined to form rates; calculations are data set. The $\Delta^{14} \mathrm{C}$ curve shows an increase with time during the Allerod and

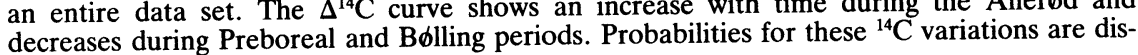
cussed.
\end{abstract}

\section{INTRODUCTION}

Results discussed here are based on several sediment cores taken in two Swiss lakes, Lobsigensee $\left(47^{\circ} 02^{\prime} \mathrm{N}, 7^{\circ} 18^{\prime} \mathrm{E}\right) 514 \mathrm{~m}$ asl and Rotsee $\left(47^{\circ} 09^{\prime} \mathrm{N}\right.$, $8^{\circ} 20^{\prime} \mathrm{E}$ ) $419 \mathrm{~m}$ asl. Both lakes have small, closed or almost closed basins and thus show undisturbed sedimentation with little allochthonous input. Both sites were studied for pollen analysis and $\delta^{18} \mathrm{O}$ measurements (Ammann et al, 1985; Lotter \& Zbinden, 1989), so we can interpret our measurements with reference to other results.

\section{MATERIAL AND METHODS}

We measured ${ }^{14} \mathrm{C} /{ }^{12} \mathrm{C}$ ratios exclusively on terrestrial macrofossils, ie, plant remains of recognizable origin (mainly birch fruit). This type of material is not affected by hard water. Old carbon introduced into the water as dissolved rock carbonate may increase the ${ }^{14} \mathrm{C}$ age of, eg, gyttja by up to 1000 yr (Andrée et al, 1986a). The scarcity of terrestrial macrofossils made the application of accelerator mass spectrometry (AMS) necessary. Sample treatment consisted in cutting samples, washing out plant debris, acid treatment and identification of terrestrial material by the Systematic Geobotanic Institute, oxidation, cleaning of gases and reduction to elemental carbon using zinc reduction method (Andrée, 1984) by Oeschger's group (low level counting, LLC), AMS measurements (Bonani et al, 1986) by the ETH group and LLC and data evaluation. 
TABLE 1

List of all ${ }^{14} \mathrm{C}$ dates from Lobsigensee and Rotsee

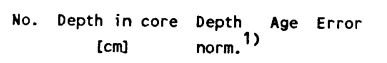

Rotsee core RL305

\begin{tabular}{|c|c|c|c|c|c|}
\hline & & 90 & & & \\
\hline 347 & 908 & 912 & & & \\
\hline & 912 & 916 & 558 & & \\
\hline & 916 & 918 & 67 & 30 & \\
\hline & 920 & & & & \\
\hline & 924 & & & & \\
\hline & 928 & דיה & & & \\
\hline 64 & 932 & 936 & 770 & 10 & \\
\hline 69 & 936 & 940 & 14 & & \\
\hline 74 & 940 & 94 & 729 & & \\
\hline 89 & 944 & 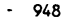 & & & \\
\hline & 948 & - 952 & 757 & & \\
\hline & 952 & -956 & & & \\
\hline & 956 & -960 & & & \\
\hline 1 & 960 & - 964 & & & \\
\hline 10 & 64 & -968 & & & \\
\hline 14 & 968 & - 972 & 20 & & \\
\hline 15 & 72 & - 976 & 38 & & \\
\hline & 6 & - 980 & & 1670 & \\
\hline & 6 & - 980 & & 230 & \\
\hline & 0 & - 984 & & & \\
\hline 34 & 984 & - & & & \\
\hline 39 & 988 & - 992 & & & \\
\hline & 992 & - 996 & & 2410 & \\
\hline & 6 & -1000 & & 30 & \\
\hline & 6 & & & & \\
\hline 2 & 1002.5 & & & & \\
\hline 3 & 10 & -1 & & & \\
\hline 4 & 10 & -10 & & & \\
\hline & 1 & -1 & & & 8 \\
\hline & & -10 & & 0 & \\
\hline & & -1024 & & & \\
\hline & & & & & \\
\hline & 10 & -10 & & & 10 \\
\hline & 103 & -10 & & & \\
\hline & 103 & -10 & & & \\
\hline & & - 1044 & & & \\
\hline & & & 50 & 10 & 22 \\
\hline & 10 & & & & \\
\hline & & -10 & & & \\
\hline & 10 & -10 & & & \\
\hline & & 1 & & & \\
\hline & & 10 & & & \\
\hline & & & & & \\
\hline & & & & & \\
\hline & & 1700 & מסכוס & & \\
\hline
\end{tabular}

Rotsee Core RL300

$\begin{array}{llllll}C 724 & 622.5-627.5 & 629 & 9450 & 140\end{array}$

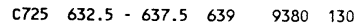
$\begin{array}{llllll}C 726 & 642.5 & -647.5 & 650 & 9770 & 130\end{array}$ $\begin{array}{lllll}\text { C727 } & 652.5 \cdot 657.5 & 661 & 9780 & 140\end{array}$ $\begin{array}{llllll}\text { C728 } & 662.5-667.5 & 671 & 9360 & 130\end{array}$ $\begin{array}{llllll}\text { C734 } & 672.5-677.5 & 682 & 10020 & 120\end{array}$ $\begin{array}{llllll}C 746 \quad 682.5 & -687.5 & 692 & 9840 & 140\end{array}$

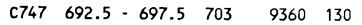
$\begin{array}{llllll}\text { C731 } & 702.5 & -707.5 & 716 & 10120 & 140\end{array}$

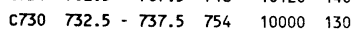
$\begin{array}{llllll}C 748 & 742.5 & 747.5 & 771 & 10920 & 170\end{array}$ $\begin{array}{llllll}\text { C732 } & 752.5 & -757.5 & 788 & 9750 & 130\end{array}$ $\begin{array}{llllll}\text { C968 } & 752.5 \cdot 757.5 & 788 & 10730 & 150\end{array}$ $\begin{array}{llllll}\text { C733 } & 762.5-767.5 & 804 & 9680 & 130\end{array}$ $\begin{array}{llllll}\text { C729 } & 772.5-777.5 & 821 & 9490 & 130\end{array}$

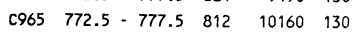
$\begin{array}{llllll}\text { C784 } 805.0-807.5 & 860 & 11440 & 140\end{array}$ $\begin{array}{llllll}C 785 & 812.5-817.5 & 874 & 11460 & 140\end{array}$ $\begin{array}{lllllll}C 781 & 822.5 & 827.5 & 887 & 11970 & 150\end{array}$ $\begin{array}{llllll}C 782 & 832.5 & 837.5 & 900 & 11870 & 150\end{array}$ $\begin{array}{llllll}\text { C783 } & 842.5-847.5 & 911 & 11800 & 140\end{array}$ $\begin{array}{llllll}C 973 & 842.5-847.5 & 911 & 11640 & 190\end{array}$ $\begin{array}{llllll}\text { C979 } & 852.5-857.5 \quad 922 & 11880 & 150\end{array}$

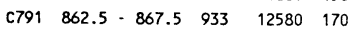

Rotsee core RL300a

$\begin{array}{llllll}C 778 & 772.5 & 777.5 & 812 & 9870 & 120\end{array}$ $\begin{array}{llllll}C 779 & 782.5 & -787.5 & 828 & 11260 & 140\end{array}$ $\begin{array}{llllll}\text { C780 } & 792.5 & 797.5 & 844 & 11270 & 140\end{array}$

1) normalized depth, see text

\section{RESULTS, ERRORS AND CORE CORRELATION}

Table 1 shows all results including those previously published (Andrée

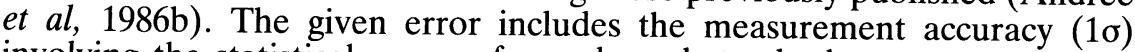
involving the statistical errors of sample and standard measurements and the long-term stability of the background as well as the error of the estimated $\delta^{13} \mathrm{C}$ value of plant material according to Stuiver and Polach (1977). 
Another error to be considered originates from the distribution of the single particles within the core section used as sample. The effective depth of the sample in the core cannot be determined precisely. This uncertainty in depth corresponds to an uncertainty in age in the range of $100 \mathrm{yr}$, depending on sample size and sedimentation rate.

To eliminate major errors due to disturbed sedimentation or other local effects, we measured several cores from two lakes. Thus, a reliable correlation of the cores was needed, for which, in principal, any recognizable feature in the core would be suitable. In our cores we found one excellent time marker, volcanic ash from Laach (LST). We also used the boundaries of local pollen assemblage zones (PAZ) to correlate within one lake and the boundaries of the regional PAZ to correlate between the two lakes. In our special case, $\delta^{18} \mathrm{O}$ is not very suitable for a correlation, because the Lobsigen $\delta^{18} \mathrm{O}$ curve shows rather atypical behavior and the resolution of the Rotsee curve is not satisfactory.

We constructed a normalized depth scale into which the depth scale of each core could be converted. The proportions of the PAZ lengths in the normalized scale correspond approximately to their average proportions in the single cores. Figure 1 shows the results of all cores plotted against the normalized depth. In general, the coincidence is satisfactory, except for the labeled values that are excluded in the final evaluation for the following reasons: 1) very small samples which required a special processing

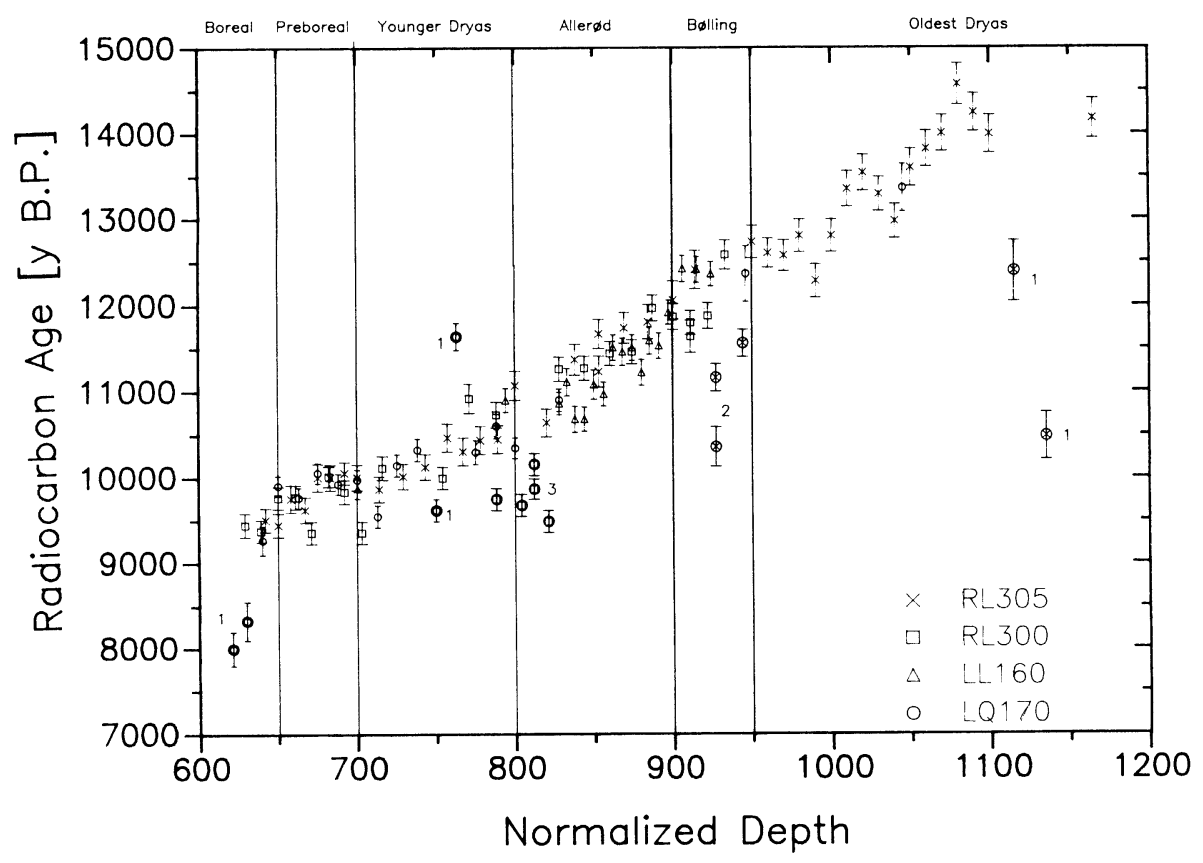

Fig $1 .{ }^{14} \mathrm{C}$ ages (BP) of the samples as a function of a normalized depth scale. Specified values (1-3), see text. 
apparatus with an increased contamination problem. We lack experience to judge the reliability of these values; 2) those samples from the top of a core segment probably originate from younger material that fell into the borehole during the coring process; 3 ) those samples that are obviously too young for unknown reasons. It strikes us that the results of core RL300 generally show larger deviations from the average trend than those of the other cores. Thus, we have rejected all results from RL300.

\section{HOW TO OBTAIN A RELIABLE TIME SCALE}

From the shape of the curve in Figure 1, two periods of nearly constant ${ }^{14} \mathrm{C}$ age can be discerned. This could be due to either a decrease in the ${ }^{14} \mathrm{C}$ concentration or an increase in the sedimentation rate, or both. If we knew the sedimentation rate, we could determine the ${ }^{14} \mathrm{C}$ variations and vice versa. We tried to estimate mean sedimentation rates with linear regressions of the ${ }^{14} \mathrm{C}$ ages. As the sedimentation has probably been changing, the core can be divided into different segments with more likely constant sedimentation rates due to constant climatic conditions. On the other hand, the shorter these segments are, the more the result is affected by the ${ }^{14} \mathrm{C}$ variations. Thus, the selection of the segments influences the outcome. We tried linear regressions, once over the whole period and then over two parts, Preboreal - Younger Dryas and Aller $\phi d-B \phi l l i n g$. This was done for each core and with the determined sedimentation rates the duration of every pollen zone was calculated. The results are compared in Table 2 . It becomes

\section{TABLE 2}

Comparison of the durations of the PAZ (D) [yr] and the sedimentation rates (S) $[\mathrm{cm} / 100 \mathrm{yr}]$ with different calculations

\begin{tabular}{|c|c|c|c|c|c|c|c|c|}
\hline \multirow{3}{*}{ 1. Regression } & \multicolumn{2}{|c|}{ Preboreal } & \multirow{2}{*}{$\begin{array}{c}\text { Younger } \\
\text { (D) }\end{array}$} & \multirow{2}{*}{$\begin{array}{l}\text { Dryas } \\
\text { (S) }\end{array}$} & \multicolumn{2}{|c|}{ Allerød } & \multicolumn{2}{|c|}{ B $\phi$ lling } \\
\hline & (D) & (S) & & & (D) & $(S)$ & (D) & (S) \\
\hline & & & & & & & & \\
\hline RL 300 & 590 & 8.1 & 865 & 8.1 & 895 & 8.1 & 525 & 8.1 \\
\hline RL 305 & 750 & 3.2 & 1000 & 3.2 & 750 & 3.2 & 500 & 3.2 \\
\hline All values & 470 & $x$ & 940 & $x$ & 940 & $x$ & 470 & $x$ \\
\hline \multicolumn{9}{|l|}{ 2. Regression } \\
\hline RL 300 & 450 & 10.6 & 660 & 10.6 & 1210 & 6.0 & 710 & 6.0 \\
\hline RL 305 & 470 & 5.1 & 630 & 5.1 & 1330 & 1.8 & 890 & 1.8 \\
\hline LL 160 & & & 1850 & 2.3 & 540 & 2.3 & & \\
\hline LQ 170 & 350 & 2.3 & 700 & 2.3 & & & & \\
\hline \multicolumn{9}{|l|}{ Varves } \\
\hline RL 300 & 500 & 9.5 & 800 & 8.8 & 800 & 9.1 & 500 & 8.5 \\
\hline RL 305 & 500 & 4.8 & 800 & 4.0 & 800 & 3.0 & 500 & 3.2 \\
\hline LL 160 & 500 & 2.9 & 800 & 4.5 & 800 & 5.3 & 500 & 2.5 \\
\hline LQ 170 & 500 & 1.6 & 800 & 2.0 & 800 & 2.8 & 500 & 2.0 \\
\hline
\end{tabular}


evident that there are considerable differences between the two approaches. As it is almost impossible to judge which partition of the core is admissible for the linear regression, another independent time scale is unquestionably necessary.

Counting varves, annual layers in the sediment, is one way to obtain a time scale. Since no varves are visible in our sediments, we refer to the Swedish varve chronology (Tauber, 1970) transferring it to our sites. Possible correlation marks that coincide are those PAZ boundaries corresponding to abrupt temperature changes that can clearly be observed in the records of both Swedish and Swiss lakes (Oldest Dryas/Bølling, Allerød/ Younger Dryas and Younger Dryas/Preboreal). The varve chronology supplies the duration of these periods (Younger Dryas: $800 \pm 50 \mathrm{yr}$, Bølling + Aller $\phi \mathrm{d}: 1300 \pm 50 \mathrm{yr}$ ). The specified errors concern the varve measurements, connections between different profiles and duplication or suppression of annual deposits according to Fromm (1970). There is also an error because the late glacial periods are not directly marked in the varve sequences. The varve ages of these periods are obtained by a more or less subjective equating of geomorphological features and halts or readvances of the ice front with the climatic changes reflected in the pollen diagrams. It seems that the localization of the Oldest Dryas/Bolling boundary is not uncontroversial, in contrast to the Younger Dryas (Tauber, 1970). The climate possibly changed quite synchronously in Switzerland and in Scandinavia, but the response of the vegetation to climatic changes is recorded with an unknown time lag. Finally, we have to consider the time resolution of the biological record. All these errors are difficult to estimate; the total error of the correlation could be in the range of 100-200 yr.

We assume the sedimentation rate to be uniform within the designated periods. The period including B $\phi 1 l i n g$ and Allerød is divided into its two parts according to the mean ratio of the lengths of the corresponding core segments from every core with known biostratigraphy. So we obtain 800 $\pm 70 \mathrm{yr}$ for the length of the Allerød and $500 \pm 70 \mathrm{yr}$ for the length of the B $\phi l l i n g$. The specified 70-yr error only concerns the scattering of the ratio; the total error is estimated at $200 \mathrm{yr}$.

The duration of the Preboreal was established similarly by comparing the length of the core segment with those of the other pollen zones. But the ratios show a systematic difference between the two lakes, so that the obtained value of $500 \pm 200 \mathrm{yr}$ is probably less reliable than the others.

Based on these durations, the normalized depth scale that equalizes minor variations in the individual cores can be converted into a time scale, assuming again uniform sedimentation within the PAZ. In Table 2, the mean sedimentation rates of the cores are calculated according to the ages estimated with the varve data. The sedimentation rates do not change excessively over the whole period, so the results seem to be quite reasonable.

Since there are no time marks in the Oldest Dryas, the time scale has to be extrapolated from the Bølling. Because the sediments changed (marl and gyttja instead of clay) the obtained values are not reliable. 
The determination of an absolute time scale, ie, the determination of the absolute age of the zero level of the chronology is one of the main problems of the varve chronology. Strömberg (1985) estimates the absolute age of the Younger Dryas/Preboreal transition at $10,700(+50,-150) \mathrm{yr}$, in good agreement with the $10,720 \pm 150 \mathrm{yr}$ obtained by Hammer et al (1986) dating an ice core from Dye 3, Greenland. We appoint 10,700 yr for the Younger Dryas/Preboreal boundary, the absolute ages of the other boundaries are determined according to the obtained durations of the PAZ (Table 3 ). A shift of the absolute time scale would cause a corresponding shift of $\Delta^{14} \mathrm{C}$ curve but not alter the shape of the curve.

TABLE 3

The time scale according to the Swedish varve chronology, ${ }^{14} \mathrm{C}$ ages of the pollen zone boundaries

\begin{tabular}{|c|c|c|c|c|c|}
\hline \multirow[t]{2}{*}{ Pollenzone } & \multirow[t]{2}{*}{$\begin{array}{l}\text { Duration with } \\
\text { estimated error }\end{array}$} & Absolute & age of boundaries & \multicolumn{2}{|c|}{${ }^{14} \mathrm{C}$ age } \\
\hline & & PB/Bo & 10,200 y cal BP & 9,700 & BP \\
\hline Preboreal & $500 \pm 200 y r$ & & & & \\
\hline & & YD/PB & 10,700 y cal BP & 10,000 & BP \\
\hline Younger Dryas & $800 \pm 150 y r$ & & & & \\
\hline & & AL/YD & 11,500 y cal BP & 10,800 & BP \\
\hline Allerbd & $800 \pm 200 y r$ & & & & \\
\hline & & Bo/Al & 12,300 y cal BP & 12,000 & BP \\
\hline Bdlling & $500 \pm 200 \mathrm{yr}$ & & & & \\
\hline & & OD/Bo & 12,800 y cal BP & 12,600 & BP \\
\hline
\end{tabular}

\section{INTERPRETATION OF THE $\Delta{ }^{14} \mathrm{C}$ CURVE}

We can now calculate $\Delta^{14} \mathrm{C}$ values using the absolute time scale obtained by the methods outlined above. Figure 2 shows $\Delta^{14} \mathrm{C}$ values plotted against absolute age. The fitted curve is based on the calculation of running means over five values. Although the scattering of the values is considerable, the following striking features of the fitted curve can be perceived:

1) a dramatic increase of nearly $100 \%$ during the Allerod;

2) two drops of $\Delta^{14} \mathrm{C}$ of ca $50 \%$ each time, once during the B $\phi l$ ling and again from the end of the Younger Dryas to the middle of the Preboreal.

Despite uncertainties in the time scale, we are convinced that the decreases are real. A horizontal segment in a ${ }^{14} \mathrm{C}$ age $v s$ depth curve always implies a decrease of $\Delta{ }^{14} \mathrm{C}$ with time. The $\Delta^{14} \mathrm{C}$ shift decreases when this period is shorter, but from the observed changes in the vegetation these periods might even last longer. The values in the Oldest Dryas are not reliable for the reasons mentioned above. So it cannot be excluded that the ${ }^{14} \mathrm{C}$ decrease of the $\mathrm{B} b l$ lling begins earlier and thus is even larger.

The apparent ${ }^{14} \mathrm{C}$ increase in the Allerød is quite surprising. It could be due to an underestimation of the duration of the Aller $\phi d$ caused by an error in the varve chronology itself or in its transfer to our sites. If the Allerød lasted $200 \mathrm{yr}$ (estimated error) longer, the increase would be reduced by ca $1 / 3(30 \%)$. To remove the whole increase, the Allerød should last $600 \mathrm{yr}$ longer. We cannot definitely exclude an error of that order. On the other 


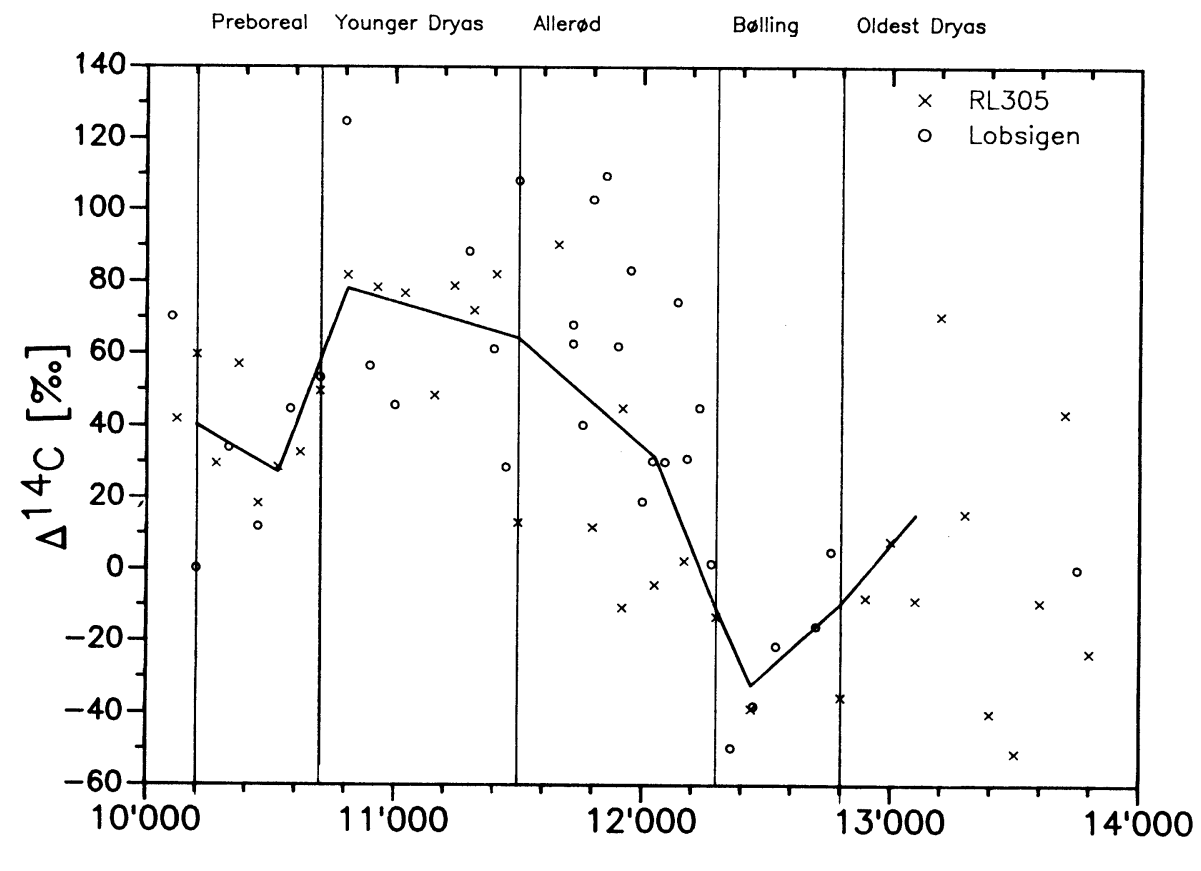

Cal BP

Fig 2. $\Delta^{14} \mathrm{C}$ as a function of time. The fitted curve is based on running means over 5 values.

hand, we have additional evidence that confirms the 1300 yr obtained fox the duration of Allerød and B $b$ lling. In the Dye 3 ice core, the ratio between the accumulation in the Younger Dryas $(\approx 10 \mathrm{~m})$ and Bølling + Aller $\phi \mathrm{d}(\approx 16 \mathrm{~m})$ is 1:1.6. If we estimate $800 \mathrm{yr}$ for the Younger Dryas, we obtain $1280 \mathrm{yr}$ for Aller $\varnothing \mathrm{d}$ and $\mathrm{B} \phi l$ ling, assuming equal accumulation rates and compression of the annual layers. The accumulation rate is supposed to be lower by about a factor of 2 during the cold Younger Dryas, whereas the rheological thinning of the annual layers is lower only by a factor of 1.1 to 1.3 (a rough estimate, Schwander, pers commun), so the duration of Bølling and Allerød could be even shorter. However, the time scale is uncertain and we have to keep that in mind during further interpretations.

Stuiver et al (1986) established $\Delta^{14} \mathrm{C}$ values reaching back to $13,500 \mathrm{cal}$ $\mathrm{BP}$ using results from the varved Lake of Clouds and several ${ }^{14} \mathrm{C}$ ages from the Swedish varve series (Tauber, 1970). Between 13,000 and 10,000 cal BP he obtains five almost constant $\Delta{ }^{14} \mathrm{C}$ values of $100 \%$ by ${ }^{14} \mathrm{C}$ matching these dates to the known tree-ring record. Stuiver's generally higher values can be explained by the fact that with ${ }^{14} \mathrm{C}$ matching, the ${ }^{14} \mathrm{C}$ value representing the Younger Dryas/Preboreal transition is ca 11,200 cal BP. The 500-yr shift in the time scale causes ca $60 \%$ higher $\Delta{ }^{14} \mathrm{C}$ values.

\section{PROBABLE CAUSES FOR THE STATED ${ }^{14} \mathrm{C}$ VARIATIONS}

${ }^{14} \mathrm{C}$ variations are due to changes either in the isotope production rate or in the carbon cycle. Variations in atmospheric ${ }^{14} \mathrm{C}$ concentration during 
the abrupt climatic change at the end of the glacial period are likely due to changes in the global carbon cycle which is strongly coupled to the global climatic system. Principally, the observed changes in atmospheric ${ }^{14} \mathrm{C}$ concentration could be established by production variations, but the measured ${ }^{14} \mathrm{C}$ variations do not show the same characteristics as the ${ }^{14} \mathrm{C}$ variations in the Holocene that are believed to reflect production variations (eg, Suess wiggles). Although an extraordinary production change cannot be excluded, we restrict the following considerations to changes in the global carbon cycle.

The temperature development at the glacial-Holocene transition is known from $\delta^{18} \mathrm{O}$ measurements of ice cores and lake sediments as well as from biological studies (Siegenthaler, Eicher \& Oeschger, 1984). It is interesting to note that $\Delta^{14} \mathrm{C}$ drops at the times of temperature increases at the beginning of the Bolling and at the end of the Younger Dryas cold phase. Atmospheric $\mathrm{CO}_{2}$ was lower during the glacial than during the Holocene; the increase starts with the first warming, but further measurements are necessary to reconstruct the exact phase relation between $\delta^{18} \mathrm{O}$ and $\mathrm{CO}_{2}$. The Younger Dryas event cannot be identified in the $\mathrm{CO}_{2}$ record (Neftel et al, 1988).

$\mathrm{CO}_{2}$ increase is probably due to changes in the ocean circulation and chemistry. The mechanisms are not yet known in detail. Several scenarios have been suggested (Broecker \& Peng, 1985). Wenk \& Siegenthaler (1985) proposed the following mechanism: an increased upwelling of $\mathrm{CO}_{2}$-rich deep water in regions where bioproductivity is not limited by the lack of nutrients would lead to a higher total carbon content in the surface water. Thus, $\mathrm{CO}_{2}$ with low ${ }^{14} \mathrm{C}$ activity would be released to the atmosphere, raising $\mathrm{CO}_{2}$ and reducing the ${ }^{14} \mathrm{C}$ concentration. Calculations with a 4-box model yield a ${ }^{14} \mathrm{C}$ increase of $35 \%$ for a $50 \%$ reduction of the exchange rate between the cold surface and the deep sea. Thus, an increased ventilation rate at the beginning of the $\mathrm{B} \phi$ lling could cause $\mathrm{a}{ }^{14} \mathrm{C}$ decrease of about the amount we have measured.

The increase of the atmospheric ${ }^{14} \mathrm{C}$ concentration during the Allerød could be established by a reduction of the $\mathrm{CO}_{2}$ exchange between atmosphere and the deep sea. The reason for such a reduction could be the influx of meltwater leading to a stable stratification of the surface water diminishing the vertical mixing of the ocean. A decrease of the ventilation rate of the deep sea by $50 \%$ leads to an atmospheric ${ }^{14} \mathrm{C}$ increase of ca $10 \%$ (Keir, 1983), ie, about the value we have measured. Of course, Keir's assumptions are arbitrary, but his calculations indicate that mechanisms of this kind could produce the observed ${ }^{14} \mathrm{C}$ increase.

To obtain the succession ${ }^{14} \mathrm{C}$ decrease - increase - decrease, it seems that the ocean has to switch between states of low and high ventilation rates. The Younger Dryas cold phase is supposed to be due to an interim transition of the system from the warm to the cold mode, possibly induced by a diversion of the discharge of Lake Agassiz meltwater from the Mississippi to the St Lawrence (Broecker et al, 1987). But in contrast to the ${ }^{14} \mathrm{C}$ decreases that are synchronous with warming, the ${ }^{14} \mathrm{C}$ increase occurs clearly before the Allerbd (warm) - Younger Dryas (cold) transition. To understand the processes occurring at the glacial/postglacial transition, more detailed 
studies of the ocean circulation are needed. The first ${ }^{14} \mathrm{C}$ measurements on benthic and planktonic forams by Andrée et al (1986a) indicate that the ventilation rate was in fact lower during the glacial.

${ }^{10} \mathrm{Be}$ measurements on ice cores by Beer et al (1988) suggested that a $20 \%$ higher ${ }^{14} \mathrm{C}$ production rate for the last $10-15 \mathrm{kyr}$ of the glacial than for the Holocene could be the reason for the long-term $\Delta^{14} \mathrm{C}$ trend of the Holocene. To confirm this proposition, much higher $\Delta^{14} \mathrm{C}$ values at the end of the glacial would be required than allowed by our study.

\section{CONCLUSIONS}

Measurements of ${ }^{14} \mathrm{C}$ on terrestrial macrofossils from lake sediments provide a method to reconstruct atmospheric $\Delta^{14} \mathrm{C}$. The main problem is to obtain a reliable time scale, a problem that may only be solved satisfactorily if the sediments show annual layers. Despite all the difficulties with time control, we obtain a rough $\Delta^{14} \mathrm{C}$ curve, which may be helpful for a correct interpretation of ${ }^{14} \mathrm{C}$ ages of this period. The determined ${ }^{14} \mathrm{C}$ variations are a hint to the behavior of the environmental system at the glacial/postglacial transition. Possible reasons for the observed ${ }^{14} \mathrm{C}$ changes have been mentioned, but we are far from fully understanding the mechanisms that occur.

\section{ACKNOWLEDGMENTS}

We thank U Siegenthaler and J Beer for valuable discussions. This work was financially supported by the Swiss National Science Foundation.

\section{REFERENCES}

Ammann, B, Oeschger, H, Andrée, M, Möll, M, Riesen, T, Siegenthaler, U, Tobolski, K, Bonani, B, Hofmann, H J, Morenzoni, E, Nessi, M, Suter, M, Wölfli, W, Züllig, H, Chaix, L, Hofmann, W, Elias, S A, Wilkinson B and Eicher, U, 1985, Lobsigensee - LateGlacial and Holocene environments of a lake on the central Swiss Plateau: Diss Bot, v 87, p 127-170.

Andrée, M, (ms) 1984, Aufbereitung von milligrammgrossen Kohlenstoffproben für AMS ${ }^{14} \mathrm{C}$ Messungen: PhD dissert, Univ Bern.

Andrée, M, Oeschger, H, Broecker, W S, Beavan, N, Mix, A, Bonani, G, Hofmann, HJ, Morenzoni, E, Nessi, M, Suter, M and Wölfli, W, 1986a, AMS radiocarbon dates on foraminifera from deep sea sediments, in Stuiver, M, and Kra, R S, eds, Internatl ${ }^{14} \mathrm{C}$ conf, 12th, Proc: Radiocarbon, v 28, no. 2A, p 424-428.

Andrée, M, Oeschger, H, Siegenthaler, U, Riesen, T, Möll, M, Ammann, B and Tobolski, K, $1986 \mathrm{~b},{ }^{14} \mathrm{C}$ dating of plant macrofossils in lake sediment, in Stuiver, M, and Kra, R S, eds, Internatl ${ }^{14} \mathrm{C}$ conf, 12th, Proc: Radiocarbon, v 28, no. 2A, p 411-416.

Beer, J, Siegenthaler, U, Bonani, G, Finkel, R C, Oeschger, H, Suter, M and Wölfli, W, 1988, ${ }^{10} \mathrm{Be}$ in the Camp Century ice core: Information on past solar activity and geomagnetism: Nature, v 331, no. 6158, p 675-679.

Bonani, G, Hofmann, HJ, Morenzoni, E, Nessi, M, Suter, M and Wölfli, W, 1986, The ETH/ SIN dating facility: A status report, in Stuiver, M, and Kra, R S, eds, Internatl ${ }^{14} \mathrm{C}$ conf, 12th, Proc: Radiocarbon, v 28, no. 2A, p 246-255.

Broecker, W S, Andrée, M, Wölfli, W, Oeschger, H, Bonani, G, Kenett, J and Peteet, D, 1987, The chronology of the last deglaciation: Implications to the cause of the Younger Dryas event: Paleoceanog, v 3, no. 1, p 1-19.

Broecker, W S and Peng, T H, 1986, Carbon cycle 1985: Glacial to interglacial changes in the operation of the global carbon cycle, in Stuiver, $\mathrm{M}$ and $\mathrm{Kra}, \mathrm{R} \mathrm{S}$, eds, Internatl ${ }^{14} \mathrm{C}$ conf,

12th, Proc: Radiocarbon, v 28, no. 2A, p 309-327. 
Fromm, E, 1970, An estimation of errors in the Swedish varve chronology, in Olsson, I U, ed, Radiocarbon variations and absolute chronology, Nobel symposium, 12th: Stockholm, Almqvist \& Wiksell, p 163-172.

Hammer, C U, Clausen, H B and Tauber, H, 1986, Ice-core dating of the Pleistocene/ Holocene boundary applied to a calibration of the ${ }^{14} \mathrm{C}$ time scale, in Stuiver, $\mathrm{M}$, and Kra, R S, eds, Internatl ${ }^{14} \mathrm{C}$ conf, 12th, Proc: Radiocarbon, v 28, no. 2A, p 284-291.

Keir, R S, 1983, Reduction of thermohaline circulation during deglaciation: the effect on atmospheric radiocarbon and $\mathrm{CO}_{2}$ : Earth \& Planetary Sci Letters, v 64, p 445-456.

Lotter, A and Zbinden, H, 1989, Late-Glacial palyno-, ${ }^{18} \mathrm{O}$ - and ${ }^{14} \mathrm{C}$-stratigraphy at Rotsee, central Swiss Plateau: Eclogae Geol Helv, v 82, no. 1, p 191-202.

Neftel, A, Oeschger, H, Staffelbach, T and Stauffer, B, 1988, $\mathrm{CO}_{2}$ record in the Byrd ice core $50,000-5,000$ years BP: Nature, v 331, no. 6157, p 609-611.

Siegenthaler, U, Eicher, $U$ and Oeschger, H, 1984, Lake sediments as continental $\delta^{18} \mathrm{O}$ records from the Glacial/Postglacial transition: Ann Glaciol, v 5, p 149-152.

Strömberg, B, 1985, Revision of the lateglacial Swedish varve chronology: Boreas, v 14, p 101105.

Stuiver, M, Kromer, B, Becker, B and Ferguson, C W, 1986, Radiocarbon age calibration back to 13,300 years $\mathrm{BP}$ and the ${ }^{14} \mathrm{C}$ age matching of the German oak and US bristlecone pine chronologies, in Stuiver, M, and Kra, R S, eds, Internatl ${ }^{14} \mathrm{C}$ conf, 12th, Proc: Radiocarbon, v 28, no. 2B, p 969-979.

Stuiver, M and Polach, H, 1977, Discussion: Reporting of ${ }^{14} \mathrm{C}$ data: Radiocarbon, v 19, no. 3 , p 355-363.

Tauber, H, 1970, The Scandinavian varve chronology and ${ }^{14} \mathrm{C}$-dating, in Olsson, I U, ed, Radiocarbon variations and absolute chronology, Nobel symposium, 12th: Stockholm, Almqvist \& Wiksell, p 173-196.

Wenk, Th and Siegenthaler, U, 1985, The high-latitude ocean as a control of atmospheric $\mathrm{CO}_{2}$ : Geophys Mono, v 32, p 185-194. 